\title{
The contribution of jurisdiction as a technique of demand side regulation in claims for the recovery of cultural objects
}

\author{
Lorna E Gillies*
}

This article considers the role of jurisdiction in supporting private claims for the cross-border recovery of cultural objects from an EU Member State. In particular, this article considers a new, "sui generis" ${ }^{1}$ special jurisdiction rule in Article 7(4) of Regulation EU 1215/2012, the Brussels I Recast Regulation. Article 7(4), inter alia, enables "(A) person domiciled in a Member State to be sued in the courts of another Member State [...] as regards a civil claim for the recovery, based on ownership, of a cultural object as defined in point 1 of Article 1 of Directive [EU 93/7] initiated by the person claiming the right to recover such an object, in the courts for the place where the cultural object is situated at the time when the court is seised." This special jurisdiction rule is a welcome development towards facilitating the return of a cultural object from the place where it is seized (for example where there is market demand or when the object is in transit), to a party asserting ownership. In practice the utility of this special jurisdiction rule will depend upon its scope and interpretation by the Court of Justice together with its ability to offer a "counterbalance" 2 to Article 4 and the other special grounds of jurisdiction in the Brussels I Recast Regulation. This paper concludes that the special jurisdiction rule is a key step towards an EU-led "transnational policy of protection of cultural property," ${ }^{3}$ which may require further approximation of EU private international law in the future.

Keywords: Brussels I Recast, cultural object, jurisdiction, recovery, ownership, enforcement, demand side regulation

\footnotetext{
* Dr Lorna E Gillies, School of Law, University of Leicester, Leicester, LE1 7RH. An earlier version of this paper was presented at the "Vulnerability and Cultural Heritage I: Heritage Crime, Illicit Trade, Stewardship and Ethics Conference," University of Leicester, May 2013 and thereafter at the " $5^{\text {th }}$ Journal of Private International Law Conference" University Autónoma de Madrid, September 2013. The author is most grateful to Professor Elena Rodriguez Pineau and Professor Symeon Symeonides for reading earlier drafts of the paper; to Ms B Sorensen at the Council of the European Union for her helpful assistance, and, to the anonymous reviewers and Journal Editors for their helpful and constructive comments. The usual disclaimer applies.

${ }^{1}$ A Briggs, Private International Law in English Courts (Oxford: University Press, 2014), 283.

2 B Hess, "The Proposed Recast of the Brussels I Regulation: Rules on Jurisdiction," in F Pocar, I Viarengo and F C Villata (eds), Recasting Brussels I: proceedings of the conference held at the University of Milan on November 25 - 26, 2011 (CEDAM, Padua, 2012), 107. Word modified for syntax.

${ }^{3}$ A Chong, "Transnational Public Policy in Civil and Commercial Matters," [2012] Law Quarterly Review 88, 106.
} 


\section{A. Introduction}

\section{The nature of the problem}

"It is demand that controls the market, and to address the illicit trade [in cultural objects], demand side control is required." 4

Cultural objects ${ }^{5}$ are representations of the identity and heritage of cultures, individuals, groups and societies. Cultural objects take numerous forms, from tangible artefacts such as tangible movable and immovable property to intangible music, song, film and dance. ${ }^{6}$ For many centuries, cultural objects - classified ${ }^{7}$ for the focus ${ }^{8}$ of this article as movable, "tangible artifacts of cultural significance" ${ }^{9}$ - have been acquired by private parties and sold legitimately in the market. However, there continues to be instances where such objects are "threaten[ed] [by] war, illicit trafficking, ${ }^{10}$ social and economic upheaval, unregulated excavation and neglect."11 Such activities often result in the objects being physically transferred to jurisdictions where market demand for such objects is high or where the objects are moved between jurisdictions for the purposes of transferring title or raising

\footnotetext{
${ }^{4}$ C Forrest, International Law and the Protection of Cultural Heritage (Routledge, Abingdon, 2010) 156. Words in square brackets added.

${ }^{5}$ As Ulph affirms, "(A) simple, universally agreed, definition of what objects can be described as cultural objects does not exist. Domestic law varies, reflecting national cultural priorities," ; J Ulph and I Smith, The Illicit Trade in Art and Antiquities, International Recovery and Criminal and Civil Liability (Hart: Oxford, 2012), 40; J Nafziger, "Introduction," in J. Nafziger (ed) Cultural Heritage Law (Edward Elgar, Cheltenham, 2012) xiii. ${ }^{6}$ J Nafziger, ibid, xiii.

${ }^{7}$ As Prott and O'Keefe confirm, “(T)he process of classification [of property] is designed to make it intellectually easier to assess the interests involved and the appropriate response"; L V Prott and P J O'Keefe "Cultural Heritage" in J Nafziger (ed) Cultural Heritage Law (Edward Elgar, Cheltenham, 2012) 9. Words added for syntax). The term 'cultural object' is used in this article to reflect the choice of this term in Regulation EU 1215/2012. ${ }^{8} \mathrm{E}$ M Cottrell, "Keeping the Barbarians Outside the Gate: Toward a Comprehensive International Agreement Protecting Cultural Property," (2009) 9 Chicago Journal of International Law 627, 633.

${ }^{9}$ Nafziger, supra n 5; J Blake, "On Defining Cultural Heritage," (2000) 49 International and Comparative Law Quarterly 61 and reproduced in Nafziger (ed), ibid, 24 referring to "material culture."

${ }^{10}$ European Commission, "Proposal For a Directive of The European Parliament and of The Council on The Return of Cultural Objects Unlawfully Removed From The Territory of a Member State (Recast)," 2013/0162 (COD) 30/05/13, 3 and European Commission, "Commission Staff Working Document Summary of the Impact Assessment, Accompanying The Document, Proposal For A Directive Of The European Parliament and of The Council on The Return of Cultural Objects Unlawfully Removed From The Territory of a Member State (Recast)," SWD (2013) 188 final, both 30/05/13.

${ }^{11}$ Forrest, supra n 4, 137-138; T Aldercreutz, "Publication Review International Law and the Protection of Cultural Heritage" (2011) 18 International Journal of Cultural Property, 397, 400.
} 
security. The legal nature of a cultural object crosses the boundary between public-private ${ }^{12}$ ownership when ownership is acquired by a third party, through commercial means such as a sale or by auction. Whilst states often attribute special status to a cultural object, it is a complex mix of public and private law which seeks to coordinate and regulate the acquisition, protection, preservation, transfer of ownership and recovery of such objects between jurisdictions. Over the last six decades, four UNESCO Conventions, one UNIDROIT Convention, one EU Regulation and two EU Directives have introduced particular public law measures with the objective of providing what Chong has previously articulated as a "transnational policy of protection of cultural property. ${ }^{\prime 13}$ Each instrument seeks to protect cultural objects in specific contexts. Whilst two of the five UNESCO Conventions enable Contracting States to seek the return ${ }^{14}$ of cultural objects removed from a jurisdiction, only the 1995 UNIDROIT Convention on Stolen or Illegally Exported Cultural Objects ${ }^{15}$ (where enacted ${ }^{16}$ ) allows a private, civil claim for the recovery of a cultural object which has been wrongfully removed.

\footnotetext{
12 On the contribution of the "public-private divide" in determining questions on cultural property, see B Kuzmarov,"The Coherence of the Concept of Cultural Property: A Critical Examination," (2013) 20 International Journal of Cultural Property 233, 236, and M A Vargas," Pondering Dysfunctions in Heritage Protection: lessons from the theft of the Codex Calixtinus," (2014) 21 International Journal of Cultural Property, 1, 2.

${ }^{13}$ Chong, supra $\mathrm{n} 3,106$.

${ }^{14}$ The words "rectification", "return" and "recovery" are used relative to the primary source.

15 "UNIDROIT Convention on Stolen or Illegally Exported Cultural Objects," available at http://www.unidroit.org/english/conventions/1995culturalproperty/1995culturalproperty-acts-e.pdf (accessed 15 April 2013) hereafter "1995 Convention."

${ }^{16}$ The EU Member States that have acceded to and implemented the 1995 Convention are Denmark, Finland, Greece, Hungary, Italy, Lithuania, Portugal, Romania, Slovakia, Slovenia, Spain and Sweden ; ibid.
} 


\section{What are we dealing with? The meaning and commodification of a 'cultural object'}

For the purposes of this article, a cultural object is classified ${ }^{17}$ as a movable, "tangible artefact [...] of cultural significance."18 The scope of this definition includes Article 1(1) of "Council Directive 93/7/EEC on the return of cultural objects unlawfully removed from the territory of a Member State."19 The definition in Article 1(1) EU 93/7, whilst "narrow in scope," ${ }^{20}$ has been an important step in "coordinating" 21 private claims for the recovery of cultural objects situated in an EU Member State. According to Article 1(1), the Directive applies to cultural objects in three respects. The first aspect is that the cultural object is "among[st] the 'national treasures possessing artistic, historic or archaeological value' under national legislation or administrative procedures [within Article 36 TFEU]." The second aspect is that the cultural object falls within one of the categories in the Annex to the Directive or is an "integral part of public collections listed in the inventories of museums [or] ecclesiastical institutions." 22 The third aspect is that the cultural object was classified as such either "before or after its unlawful removal from the territory of a Member State."

Directive 93/7/EEC applies to situations where a cultural object has been "unlawfully removed [... or] not returned after a period of lawful temporary removal [...]." ${ }^{23}$ For example, a tangible cultural object may be illegally excavated, exported, stolen from or not returned to

\footnotetext{
17 See supra $\mathrm{n} 7$.

${ }^{18}$ Nafziger, supra $\mathrm{n} 5$, xiii ; J Blake, supra $\mathrm{n} 9$.

${ }^{19}$ Council Directive 93/7/EEC on the return of cultural objects unlawfully removed from the territory of a Member State 1993 OJ L74 (hereafter Directive 93/7/EEC).

${ }^{20}$ Ulph, supra $\mathrm{n} 5,184$.

${ }^{21}$ Nafziger, supra n 5, xxii; "Directive 2014/60/EU on the return of cultural objects unlawfully removed from the territory of a Member State and amending Regulation (EU) No.1024/2012 (Recast)," Recitals 5 and 6. This Directive will replace Directive 93/7/EEC with effect from 19 December 2015; OJ L159/1, 28/05/14.

${ }^{22}$ Article 1(1), Directive 93/7/EEC.

${ }^{23}$ Article 1(2), Directive 93/7/EEC.
} 
Country A (the supply State). It may then be transferred to Country B (a demand or transit state) for the purposes of acquiring good title under the law of Country B. It may then be sold to an innocent third purchaser in Country B or Country C (another demand state). The 'market' for cultural objects is increasingly international with buyers and sellers situated in different jurisdictions. In 2011, Nafziger estimated that the value of stolen (illicit) cultural objects was "as high as $\$ 4$ billion annually." ${ }^{24}$ There is also a corresponding concern with the "commoditization" 25 of licit objects in response to market demand. Recent examples which necessitate the cross-border interest in and sustained commercial demand for tangible, cultural objects ${ }^{26}$ include the authorisation by a French court for the sale of seventy Hopi sacred objects - with a combined estimated value of US\$1 million ${ }^{27}$ - and the removal of graffiti art from a building in London, England to Florida, United States, its sale in Florida and subsequent return for auction in London. ${ }^{28}$

In fostering an established "legal order" 29 for the protection of cultural objects, the coordination of rules to facilitate civil claims for the return of a cultural object wrongfully removed from a Member State should operate in tandem with both established international

\footnotetext{
${ }^{24}$ Nafziger (ed), supra $\mathrm{n} 5, x v i$.

${ }^{25}$ L V Prott and P J O'Keefe, supra n 7, 7 ; Ulph and Smith, supra n 5, 4.

${ }^{26}$ The highest contemporary art sale (US\$495m) took place in New York: BBC News, “Christie’s Auction Sale "highest in auction history,"” (BBC News, 16 May 2013) at <http://www.bbc.co.uk/news/entertainment-arts$\underline{22552373}$ > accessed 16 May 2013.

27 BBC News, "Paris Judge Allows Auction of Arizona Masks," (BBC News, 12 April 2012) at <http://www.bbc.co.uk/news/world-europe-22120133> accessed 12 April 2013. Had these sacred objects been the property of a French museum, they would have been provided with the level of protection afforded to Stateowned objects; Prott and O'Keefe, supra n 7, 11.

${ }^{28}$ BBC News, "Taken Banksy is Withdrawn from sale," (BBC News, 24 February 2013) at <http://www.bbc.co.uk/news/entertainment-arts-21562042> accessed 24 February 2013 and subsequently BBC News, "Banksy"s Slave Labour Mural Auctioned in London," (BBC News, 2 June 2013) at <http://www.bbc.co.uk/news/entertainment-arts-22749345> accessed 2 June 2013.

${ }^{29} \mathrm{~F}$ Francioni, "Plurality and Interaction of Legal Orders in the Enforcement of Cultural Heritage Law," in F Francioni and J Gordley (eds), Enforcing International Cultural Heritage Law, (Oxford: University Press, 2013), 9-10.
} 
conventions and alternative means of redress. Whilst attractive, alternative means of redress through mediation and arbitration still predominantly remain developing mechanisms for securing the recovery of cultural objects. This article therefore focusses on the continued contribution of private international law, specifically the role of jurisdiction, ${ }^{30}$ in supporting a civil claim by a party for the recovery of a tangible, movable cultural object that has been removed by theft or illegal export to an EU Member State. This article focusses on the new, special jurisdiction rule in Regulation EU 1215/2012 (the Brussels I Recast Regulation) for private claims by a party asserting ownership for the recovery of a cultural object. This special jurisdiction rule is a welcome development towards facilitating the return of a cultural object to a party asserting ownership. However, in practice the utility of this special jurisdiction rule will depend upon its scope and interpretation by the Court of Justice and its ability to offer a "counterbalance" 31 to Article 4 and the other special grounds of jurisdiction in the Brussels I Recast Regulation. This paper examines the special jurisdiction rule as a step towards an EU "transnational policy of protection of cultural property," 32 and will consider whether in the longer term further approximation of EU private international laws for the coordination of civil claims concerned with cultural objects may be necessary to ensure protection and return.

\section{Changing legal responses to recovery of cultural objects via private claims}

For over two centuries, international law has provided that States have a general "duty"33 to "explicitly designate ... protection" 34 for cultural objects, including negotiating for their

\footnotetext{
${ }^{30}$ On choice of law issues see, for example, P. Youngblood Reyhan, "A Chaotic Pallate: Conflict of Laws in Litigation between Original Owners and Good-Faith Purchasers of Stolen Art," in J Nafziger (ed), Cultural Heritage Law (Edward Elgar, Cheltenham, 2012), 617.

${ }^{31}$ B Hess, in F Pocar, I Viarengo and F C Villata (eds), supra n 2, 107. Word modified for syntax.

${ }^{32}$ Chong, supra $\mathrm{n} 13,106$.

33J Fawcett and JM Carruthers, Cheshire, North and Fawcett's Private International Law (Oxford University Press, 14th edn, 2008), 1223.

${ }^{34}$ Cheshire and North, ibid.
} 
restitution, preservation and regulation. ${ }^{35}$ Such duty reflects the "principle of respect" ${ }^{36}$ for cultural objects as objects of national identity ${ }^{37}$ on the one hand and as objects of international cultural heritage $\mathrm{e}^{38}$ on the other. For almost the last four decades, the emphasis and contribution ${ }^{39}$ of public international law has been on the "restitution of cultural objects to their country of origin." 40

The legal response to securing the recovery of cultural objects continues to be influenced $^{41}$ by the debates between post-cultural internationalism ${ }^{42}$ and cultural nationalism. ${ }^{43}$ The former is concerned with the necessity for wider protection of cultural heritage for the whole of humanity whilst the latter has focussed on respecting the rights of the state as owner of the object. The EU has sought to contribute to this debate by protecting the cultural nationalism of the EU Member States. It seeks to achieve this through the "mutual recognition of Member States' laws"44 and the "moral and material"45 return of a cultural object to the original owner (whether a State, indigenous group, ${ }^{46}$ private ${ }^{47}$ or natural

\footnotetext{
${ }^{35} \mathrm{~A}$ F Vrdoljak, International Law, Museums and the Return of Cultural Objects (Cambridge; University Press, 2006), 202, 204.

${ }^{36}$ F Francioni, "The human dimension of international cultural heritage law: an introduction," (2011) European Journal of International Law 9.

${ }^{37}$ Vrdoljak, supra n 35, 205.

${ }^{38}$ Forrest, supra n 4, 145; Vrdoljak, supra n 35, 204.

39 J M Carruthers, The Transfer of Property in the Conflict of Laws, (Oxford: OUP, 2005), 132-133, 137, 143.

${ }^{40}$ Vrdoljak, supra $\mathrm{n} 35,206$.

${ }^{41}$ F Francioni and J Gordley (eds), Enforcing International Cultural Heritage Law, (Oxford: University Press, 2013).

${ }^{42}$ Vrdoljak, supra n 35, 210; L V Prott, "The International Movement of Cultural Objects," (2005) International Journal of Cultural Property 225, 228-231.

43 J H Merryman, "Two Ways of Thinking about Cultural Property," (1986) 80 American Journal of International Law 831.

${ }^{44}$ Directive EU 2014/60, Recital 6, supra $\mathrm{n} 21$.

${ }^{45}$ Vrdoljak, supra $\mathrm{n} 35,299$. On the utility of ADR methods see M Cornu and M A Renold, "New Developments In The Restitution of Cultural Property: Alternative Means of Dispute Resolution," (2010) International Journal of Cultural Property 1, 7; cf where the authors observe that agreements between Italy and several US museums for the loan and restitution of cultural objects "quite surprisingly ... contained no choice of law clause," 19. Words removed for syntax.

${ }^{46}$ Vrdoljak, ibid.

47 The Draft Common Frame of Reference proposes, as a minimum harmonisation rule, that ownership of a cultural object requires "continuous possession" for a period of either thirty years (with good faith) or fifty
} 
person, ${ }^{48}$ or museum). Such an approach may go some way to "reconstitut[ing] individual and group identities." ${ }^{49}$

The increased commercial value or demand for cultural objects has prompted a change in normative legal and procedural responses. ${ }^{50}$ As stated earlier, only the 1995 UNIDROIT Convention enabled a private claim for the recovery of a cultural object. This Convention provides a minimum level of substantive and procedural "uniform rules"51 to facilitate claims by private individuals for the restitution of stolen cultural objects (Chapter II) or the return of illegally exported cultural objects (Chapter III), ${ }^{52}$ contrary to a Contracting State's export laws. The 1995 Convention contains a variety of minimum substantive and procedural rules. For example, in cases of theft Article 3(3) provides a general limitation period of fifty years, reduced to three years if the claimant was aware of the location of the object and the party in possession of it. Article 3(4) provides that if the cultural object is "an integral part of an identified monument or archaeological site, or [part of] a public collection" the general limitation period does not apply unless the claimant knew the location of the cultural object and the party in possession of it has been identified. Articles 4 and 6 both provide that the possessor of a cultural object is entitled to "fair and reasonable

\footnotetext{
years (both of which are less than the 1995 UNIDROIT Convention, considered below); C. Von Bar, E. Clive and H. Schulte-Nolke, Principles, Definitions and Model Rules of European Private Law, Draft Common Frame of Reference (DCFR), (Outline Edition, Sellier, European Law Publishers, 2009) at VIII-4:102.

${ }^{48}$ Government of Iran v Barakat Ltd [2007] ECWA Civ 1374.

49 T. O'Donnell, "The restitution of Holocaust looted art and transitional justice: the perfect storm or the raft of the Medusa?" (2011) 22 European Journal of International Law 49, 49. Words modified for syntax.

${ }^{50}$ Cornu and Renold, supra n 45, 7 ; contrast the function of "ethical rules and codes of honor" in M Frigo, "Ethical Rules and Codes of Honour Related To Museum Activities: A Complementary Support To The Private International Law Approach Concerning The Circulation of Cultural Property," (2009) International Journal of Cultural Property 49.

${ }^{51}$ Forrest, supra $\mathrm{n} 4,197$.

52 At present, thirty three Contracting States have acceded to this Convention; "Status of the UNIDRIOT Convention on Stolen or Illegally Exported Cultural Objects": <http://www.unidroit.org/english/implement/i95.pdf $>$ available at <http://www.unidroit.org/instruments/cultural-property/1995-convention> accessed 15 April 2013. In the last decade, this figure represents a three-fold increase; see Carruthers, supra $\mathrm{n} 39,134$.
} 
compensation" where that party exercised due diligence and was not aware that the object had been either stolen or illegally exported. The Contracting State in which the claim is brought must be satisfied that the foreign law breached is an export law, not a tax, revenue or penal law. Article 8 provides that a claim for return may be brought where the cultural object is located. However, this has been subject to Contracting States' existing jurisdiction rules. Furthermore, by enabling provisional or protective measures to be initiated in the courts for the place where the object is found, Article 8(3) of the 1995 Convention provides an analogous provision to Article 35 of the Brussels I Recast Regulation.

There are three broad techniques for the private "regulation and control" 53 of tangible cultural objects. The first technique is through transferring title via the substantive law. As with other forms of tangible, movable property, national substantive laws require parties to establish provenance and exercise due diligence when acquiring or transferring title of such property by sale or auction. The "appropriate transfer, and safe return [of] cultural material"54 is generally subject to the law of the place where the property is situated (lex situs). ${ }^{55}$ The second technique through the application of export laws. States may apply export conditions, restrictions or prohibitions ${ }^{56}$ as export (supply), ${ }^{57}$ import (demand) or intermediate/transit ${ }^{58}$ states. The third technique is provided by private international law. In particular, determining when it is appropriate to permit a private party to assert jurisdiction in civil proceedings for recovery of a cultural object. As Forrest explains

\footnotetext{
${ }^{53}$ Nafziger (ed), supra $\mathrm{n} 5, x v$.

${ }^{54}$ Nafziger, supra $\mathrm{n} 5, x v i$.

55 Youngblood Reyhan, in Nafziger, supra n 30, 622 ; Nafziger, at xvi. Word in brackets modified for syntax. ${ }^{56}$ 2013/0162 (COD), 30/05/13, supra n 10, 2 and 3.

${ }^{57}$ Forrest, supra $\mathrm{n} 4,157-160$, where the author considers the "retentionist" approach via export regulations.

58 The term "transit State" is used by Prott in the context of the 1995 UNIDROIT Convention; L V Prott, Commentary on the UNIDROIT Convention on Stolen and Illegally Exported Cultural Objects 1995, (Institute of Art and Law, Leicester, 1997) 16, and by Forrest, supra n 4, 138.
} 
"... the problem [to be] addressed is the movement of cultural heritage from one entity to another where the entity has lost possession of the cultural heritage [...] This necessarily raises not only complex notions of cultural identity, but also legal issues of ownership, possession and control." 59

Assuming "autonomy"60 of legal ownership of the object persists in the country of origin (Country A), the subsequent loss of the right ${ }^{61}$ to possess the object and the acquisition of res extra commercium ${ }^{62}$ status through theft or illegal export to another jurisdiction (Country B or $\mathrm{C}$ in the above example) provides an opportunity to review the role of private international law in "demand side regulation and restraint." ${ }^{63}$ In 2011, the European Commission launched a consultation for the revision of Directive EU 93/7 on the "Return of Cultural Objects Unlawfully Removed from EU Member Countries." However, this Directive only equips Member States with the ability to bring patrimonial claims for the return of cultural objects classified as national treasures in accordance with Article 1(1) of the Directive. As far as private parties are concerned, further approximation of Member States' private international laws for the benefit of the internal market commenced with the introduction of a "sui generis"64 special jurisdiction rule in Regulation EU 1215/2012, the Brussels I Recast Regulation. ${ }^{65}$ The essence of this new jurisdiction rule, contained in Article $7(4)$ is to give private parties greater choice of jurisdiction for making a claim for the recovery of cultural objects. ${ }^{66}$ It is this third technique to which we now turn.

\footnotetext{
${ }^{59}$ Forrest, ibid, 136, words added and removed for syntax.

${ }^{60}$ Carruthers, supra $\mathrm{n} 39,143$.

${ }^{61}$ Forrest, supra $\mathrm{n} 4,148$.

62 Nafziger, supra n 5, xiv.

${ }^{63}$ Forrest, supra n 4, 219.

${ }^{64}$ A Briggs, Private International Law in English Courts (Oxford: University Press, 2014), 283.

65 "Regulation EU 1215/2012 of the European Parliament and of the Council of 12 December 2012 on jurisdiction and the recognition and enforcement of judgments in civil and commercial matters (recast)," [2012] OJ L351/1.

${ }^{66}$ Forrest, supra n 4, 219 ; Carruthers, supra n 39, 143; P Rogerson, "Jurisdiction for the Retrieval of Cultural Objects" in A Dickinson and E Lein (eds) The Brussels I Regulation Recast (Oxford University Press, 2015) 174176.
} 


\section{B. The emerging role of EU jurisdiction rules in the recovery of cultural objects}

According to Nafziger,

“... claims for the return, restitution, or repatriation of cultural heritage have been of central importance." 67

When a cultural object has been removed from one jurisdiction to another and a claim for its return is sought, the matter will require reference to rules of private international law. The nature of the claim must be classified, either as a patrimonial claim by the state or a private claim by a legal or natural person. The cultural object must be identified ${ }^{68}$ and the location of the defendant ${ }^{69}$ with physical possession of the object must be established. For Regulation EU 1215/2012 to apply, the defendant's domicile in a Member State must be established in accordance with Article 4. As with the other special jurisdiction rules in Article 7, for Article 7(4) to operate correctly, the Member State where the object is situated must be a distinct jurisdiction from where the defendant is domiciled. Once the nature of the claim is determined and jurisdiction is established, the applicable law rules of the court seised will apply. Each Member State applies its own applicable law rule (predominantly the lex situs) to determine what substantive law applies to questions of (inter alia) ${ }^{70}$ ownership and the essential ${ }^{71}$ validity of any transfer of ownership between the parties. ${ }^{72}$ Carruthers has

\footnotetext{
${ }^{67}$ Nafziger (ed), supra $\mathrm{n} 5, x v i$.

68 Ulph and Smith, supra $\mathrm{n}$ 5, 174-176.

${ }^{69}$ In practice, either the possessor (Article 1(6)) or holder (Article 1(7)) of the cultural object; Directive 93/7/EEC.

${ }^{70}$ Carruthers, supra $\mathrm{n}$ 39, 80-81; Council of the European Union, "Proposal for a Regulation of the European Union and of the Council on jurisdiction and the recognition and enforcement of judgments in civil and commercial matters (Recast), Note of the delegations of the United Kingdom and Cyprus on Article 5(2)," JUSTCIV 92, CODEC 707, 19 March 2012.

${ }^{71}$ L Collins et al (eds), Dicey, Morris and Collins, The Conflict of Laws (15th edn, Sweet and Maxwell, 2014), para 34-026.

72 It is settled that the lex situs, as the law of the place where the tangible property is situated, determines questions concerned with the nature, control of or title to such property. In England, it is applied as a strict choice of law rule: $U$ Devlin in Bank voor Handel en Scheepvaart NV v Slatford (No 1) [1951] 2 All ER 779 ; Winkworth v Christie Manson and Woods Ltd [1980] Ch 496; Dicey and Morris, ibid, para 24-005; Cheshire and
} 
previously observed that, whilst distinct, issues of jurisdiction, ${ }^{73}$ applicable law and enforcement must nevertheless "interact" $"$ with one another. Recent legislative developments at EU level highlight that the "salient"75 role of the court seized (and thereby the lex fori) where a cultural object ${ }^{76}$ is situated has increased. The jurisdiction rule for the recovery of cultural objects unlawfully removed from a Member State in Regulation EU $1215 / 2012^{77}$ is a welcome development in furthering the principle of mutual recognition of Member States' cultural objects and in providing judicial protection of cultural objects which may have been brought to an EU Member State.

\section{The role of the court seised under the EU regime: classification and jurisdiction}

Prior to the introduction of the "alternative"78 jurisdiction rule in Regulation EU 1215/2012, there was no special in rem jurisdiction rule for the recovery of movable property in Regulation EU 44/2001, the Brussels I Regulation. Article 3(2) and Annex 1 of Regulation EU 44/2001 state that as far as the EU domiciled defendants are concerned, jurisdiction cannot be established under that Regulation (inter alia) on the basis of seizure of property in the jurisdiction. Such jurisdiction has traditionally ${ }^{79}$ been regarded as exorbitant. In addition,

North, supra $\mathrm{n} 33,1224$. Given the potential impact on the rights of the claimant and of third parties in claims for the recovery of a cultural object, attention may turn to the putative applicable law, the application of foreign law and the public policy rules of the court seised.

${ }^{73}$ Fawcett refers to the "underlying basis of the jurisdiction is a choice of law rule"; 1991 Current Legal Problems 39 ; Carruthers, supra n 39, 39.

${ }^{74}$ Carruthers, supra n 39, 38; P Rogerson, "Case Comment: Public Policy and Cultural Objects," (2008) Cambridge Law Journal 246.

${ }^{75}$ Cottrell, supra n 8, 637.

${ }^{76}$ Chong, supra $\mathrm{n} 13$.

77 Brussels I Recast, supra $\mathrm{n} 65$.

78 Z C Reghizzi, "A New Special Forum for Disputes Concerning Rights in Rem over Moveable Assets: Some Remarks on Article 5(3) of the Commission's Proposal," in F Pocar, I Viarengo and F C Villata (eds), Recasting Brussels I : proceedings of the conference held at the University of Milan on November 25 - 26, 2011 (CEDAM, Padua, 2012), 173.

${ }^{79}$ M Weser, "Litigation on the Common Market Level," (1964) American Journal of Comparative Law 44 ; G Maher and B J Rodger, Civil Jurisdiction in the Scottish Courts (W Green: Edinburgh, 2010), 116-117. 
there appeared to be theoretical and practical challenges in establishing jurisdiction for the recovery of cultural objects on the basis of general or other special jurisdiction rules under EU 1215/2012, which will now be briefly considered.

The starting points are Recitals 8 and 11. Recital 8 necessitates a "link between proceedings to which this Regulation applies and the territory of the Member States bound by this Regulation." Recital 11 reaffirms that a departure from the defendant's domicile as the general rule is permissible on "subject-matter [or] party autonomy" grounds. The application of the defendant's domicile as general jurisdiction for claims for the recovery of tangible cultural objects is open, but tenuous if neither the defendant nor his domicile is known to the claimant. As the claim falls within the material scope of the Regulation, the defendant's current (or possibly last known ${ }^{80}$ ) domicile under Article 4 could be utilised in claims for the recovery of a cultural object. ${ }^{81}$ The "alternative" ${ }^{82}$ special grounds of jurisdiction in Articles 7(1) and 7(2) are also of limited use. Unless the parties have a prior contractual relationship, the circumstances upon which the wrongful removal of a cultural object between jurisdictions is unlikely to constitute a "matter relating to contract" under Article $7(1)$. It remains a moot point as to whether the wrongful removal of a cultural object constitutes a "breach of obligation" ${ }^{83}$ between the parties which would give rise to a claim in tort under Article 7(2). Taking account of the Court of Justice's earlier decisions in Kalfelis $v$ Schroder, ${ }^{84}$ Rudolf Gabriel ${ }^{85}$ and more recently in Melzer, ${ }^{86}$ Article 7(2) could only apply by

\footnotetext{
${ }^{80}$ Case C-327/10 Hypotecní banka, a.s. v Udo Mike Lindner, [2011] ECR I-1154.

${ }^{81} \mathrm{Cf}$ opinion of the Court of Appeal of Liege in $X v Y 13$ December 2012 that a claim for restitution fell within the scope of the Brussels I Regulation on the application of Article 2; <http://www.ipr.be/tijdschrift/tijdschrift46.pdf> accessed 16 August 2013.

82 Maher and Rodger, supra $\mathrm{n} 79,5$.

83 Briggs, supra $n$ 64, 283.

${ }^{84}$ Case 189/87 Kalfelis v Schroder [1988] ECR 5565.

${ }^{85}$ Case C-96/00 Rudolf Gabriel [2002] ECR I-6367.

${ }^{86}$ Case C-228/11, Melzer v MF Global UK Ltd ECLI:EU:C:2013:305.
} 
analogy to an in personam claim in tort in the courts of the place where the cultural object was wrongfully removed or not returned after a period of lawful removal (in accordance with Article 1(2) Directive EU 93/7). In accordance with recent authority from the Court of Justice in Wintersteiger AG v Products $4 U$ Sondermaschiinenbau and Pinckney $v$ Mediatech, ${ }^{87}$ both places could constitute the place of damage or the event giving rise to it. Furthermore, as the delegation of Cyprus to the Council of the European Union confirmed, an action under Article 7(4) "is a property action [...] It is not a tort action..." ${ }^{88}$

Where the defendant is not domiciled in a Member State, Article 5 refers the matter to Member States' residual jurisdiction. ${ }^{89}$ For both English and Scottish residual jurisdiction rules to operate against a non-EU defendant in personam, the movable property at issue must be located in those jurisdictions. In England, service out of the jurisdiction requires the permission of the court in accordance with Civil Procedure Rules 6.36 Practice Direction 6B Paragraph 3.1.11. ${ }^{90}$ Given the nature of movable property, as Briggs and Rees rightly observe, this jurisdiction rule is wide in its scope. ${ }^{91}$ However the balance should be found in the procedural requirements for jurisdiction. The claimant must show that there is a serious issue to be tried and that in accordance with Spiliada Maritime Corp., $v$ Cansulex Ltd $^{92}$ England is the appropriate forum in the interests of the parties and the ends of justice. The equivalent basis of jurisdiction in Scotland is Rule 2(i) of Schedule 8 to the Civil Jurisdiction and Judgments

\footnotetext{
${ }^{87}$ Case C-523/10 Wintersteiger AG v Products 4 U Sondermaschiinenbau ECLI:EU:C:2012:220 ; Case C-170/12 Pinckney v Mediatech ECLI:EU:C:2013:635.

${ }^{88}$ Council of the European Union, "Proposal for a Regulation of the European Parliament and of the Council on jurisdiction and the recognition and enforcement of judgments in civil and commercial matters (Recast) Comments from the delegation of Cyprus relating to Article 5(2)," JUSTCIV 223, CODEC 1593, 7 June $2012,2$. ${ }^{89}$ L Gillies, "Creation of Subsidiary Jurisdiction Rules In The Recast Of Brussels I: Back To The Drawing Board?" (2012) 8 Journal of Private International Law 489.

${ }^{90}$ CPR, Practice Direction 6B, "Service out of the Jurisdiction," Paragraph 3.1.11.

${ }^{91}$ A Briggs and P Rees (ed), Civil Jurisdiction and Judgments (5 ${ }^{\text {th }}$ ed, Lloyds, 2009), 519 at para. 4.68.

92 Spiliada Maritime Corp. v Cansulex Ltd [1987] AC 460.
} 
Act 1982 (as amended). ${ }^{93}$ The claimant may alternatively try to bring proceedings against a non-EU domiciled defendant in tort. In England, if the claimant wished to sue in tort for conversion, he would have to seek the court's permission to "serve out" and demonstrate a connection with England under CPR 6.36 Practice Direction 3.1.9 that damage to the property was sustained in the jurisdiction. In Scotland, an action in delict ("spuilzie") may be brought against a non EU defender under Rule 2(c) of Schedule 8 to the 1982 Act if Scotland was the place where damage occurred to movable property. These rules may be subject to the defendant's plea of forum non conveniens ${ }^{94}$ in applying for a stay (in England) or sist (in Scotland) of proceedings.

\section{2. "Demand side control"95 of cultural objects in Regulation EC 1215/2012}

Thirty five years ago, a UNESCO Committee - in accordance with Cornu's observation recommended Members should seek "ways and means of facilitating bilateral negotiations for the return of cultural property to its countries of origin." ${ }^{\prime 96}$ As a result of the review of the Brussels I Regulation, the proposal for an additional special jurisdiction for disputes concerned with the recovery of cultural objects ${ }^{97}$ (as defined by Directive $93 / 7 \mathrm{EC}$ ) was accepted. In the original proposal for Regulation EU 1215/2012, the European Commission proposed a new Article 5(3) which would have provided a lex specialis jurisdiction rule for "rights in rem or possession of movable property" being "the courts for the place where the property is

\footnotetext{
${ }^{93}$ Hereafter "the 1982 Act." See P Beaumont and P McEleavy, Anton: Private International Law (3 ${ }^{\text {rd }}$ ed, W Green/SULI, Edinburgh, 2011) 327-329. But see also in Scotland the much broader jurisdiction available in relation to arrestment of moveables under Rule 2(h)(i) of Schedule 8 to the 1982 Act; see Anton, ibid, 320-325.

${ }^{94}$ Cottrell, supra $\mathrm{n} 8,638$ and Anton, ibid, 359-367.

${ }^{95}$ Forrest, supra $\mathrm{n} 4,156$.

${ }^{96}$ Cornu and Renold, supra $\mathrm{n} 45,3$.

97 B Hess, T Pfeiffer and P Schlosser, The Brussels I Regulation (EC) No 44/2001, The Heidelberg Report on the Application of Regulation Brussels I in 25 Member States (Study JLS/C4/2005/03), (Verlag C.H. Beck, 2008).
} 
situated." 98 The origins of the proposal can be traced back to the Heidelberg Report. In that report, it was noted that Germany suggested the need for a "non-exclusive ground of jurisdiction ... based on the situs of movable assets as far as rights in rem of possession are concerned." 99 The Rapporteurs of the Heidelberg Report confirmed that there was "some merit ..."100 in introducing a fact-based/specific ground of jurisdiction and went on to recommend "establishing a (non-exclusive) forum based on the situs of movable property for cases where this property is the object of the controversy."101 The "express innovation"102 of the initial proposal was to facilitate in rem jurisdiction as an alternative to in personam claims based either on the defendant's domicile or one of the other special grounds of jurisdiction such as Article 7(2), briefly considered above. In addition, Reghizzi suggests that the justification for a special jurisdiction rule stemmed from concerns regarding enforcement of judgments in such cases where a judgment was obtained from a non-Member State. ${ }^{103}$

The scope and content of the proposal for in rem jurisdiction over tangible, movable property was subsequently proposed as two discrete Options by a joint delegation of the United Kingdom and Cyprus and presented to the Council of the European Union. The delegations presented two options which contained the following elements. The first, and wider, option proposed that Article 5(2) (as it then was numbered) could establish jurisdiction over tangible, moveable property where "a violation of rights in rem..."104 had occurred. The

\footnotetext{
98 European Commission, "Proposal for a Regulation of the European Parliament and of the Council on jurisdiction and the recognition and enforcement of judgments in civil and commercial matters (Recast)," 2010/0383 (COD), 14.12.2010, COM (2010) 748 final at p.24. Words italicised for emphasis.

${ }^{99}$ Hess, Pfeiffer and Schlosser, supra $\mathrm{n}$ 97, 73-74, para.153-154.

100 Hess, Pfeiffer, Schlosser, ibid.

${ }^{101}$ Hess, Pfeiffer, Schlosser, ibid, 140, (para. 402) and 352 (para.876); Reghizzi, supra n 78, 174.

102 B Hess, in Pocar, Viarengo and Villata (eds), supra $\mathrm{n}$ 1, 106.

${ }^{103}$ Reghizzi, supra $\mathrm{n} 78,180$.

${ }^{104}$ Council of the European Union, "Proposal for a Regulation of the European Parliament and of the Council on jurisdiction and the recognition and enforcement of judgments in civil and commercial matters (Recast) Drafting proposal for Article 5(2)," JUSTCIV 214 CODEC 1519, 8 June 2012.
} 
proposal specified that the temporal scope would be established "at the time the court is seised." 105 The delegation also affirmed that Article 35 could be used to secure provisional or protective measures in an alternative jurisdiction to the forum in question. ${ }^{106}$ The aim of Article 35 is to provide a protective and strategic tactic ${ }^{107}$ in litigation. Its objective is to provide a "speedy"108 mechanism for a claimant to seek a "provisional or protective"109 measure from a court in one or more Member States either at the initial ${ }^{110}$ or subsequent $^{111}$ stages of the litigation process. Measures sought under Article 31 may apply within the Member State, on an extra-territorial basis and/or against third parties, subject to rules on enforcement under Article 34. According to Masri v Consolidated Contractors (International) (UK) Ltd, a measure which is intended to apply extra-territorially must do so in accordance with "international law or comity." 112 The purpose of a (national) measure under Article 31 may be to "maintain the status quo ... prevent ... asset dispos[al] [or to facilitate] investigation." 113 Measures which facilitate these purposes are relevant as far as disputes concerning cultural objects are concerned. ${ }^{114}$ Firstly, the measure may ensure that the cultural object remains in a particular jurisdiction, whilst proceedings under Article 7(4) continue. For example, Rule 25 of the English Rules of Civil Procedure (CPR) enables (inter alia) the sale of property. ${ }^{115}$ Second, the measure sought may prevent asset disposal to

\footnotetext{
105 Council of the European Union, CODEC 707, supra $\mathrm{n} 70,1-2$.

106 Briggs and Rees, supra $\mathrm{n} 91,139,634$, para 6.01.

107 T Kruger, Civil Jurisdiction Rules of the EU and Their Impact on Third States (Oxford; University Press, 2008), 353.

108 Kruger ibid, 352

${ }^{109}$ As distinct from interim; section 25, 1982 Act ; G Maher and B J Rodger "Provisional and Protective Remedies: the British experience of the Brussels Convention," (1999) 48 International and Comparative Law Quarterly 302, 306; J Newton, The Uniform Interpretation of the Brussels and Lugano Conventions (Hart Publishing, 2002 ), 287. ${ }^{110}$ Maher and Rodger, ibid, 302.

111 Maher and Rodger, ibid, 309-310.

112 Masri v Consolidated Contractors (International) (UK) Ltd (No.2) [2009] QB 450 at 465.

$113 \mathrm{~J} \mathrm{Hill}$ and A Chong, International Commercial Disputes Commercial Conflict of Laws in English Courts $\left(4^{\text {th }}\right.$ ed, Hart, Oxford, 2010), 337-338. Words removed, modified and added for syntax.

114 Hill and Chong ibid, 337.

115 CPR Rule 25.1 (1) (c).
} 
another party in the same or another jurisdiction. For example, Rule 25 of the CPR enables a party to enter premises in order to retain property ${ }^{116}$ or to freeze the defendant's assets. ${ }^{117}$ Following the Court of Justice's approach in Van Uden, there must be a "real connecting link"118 $^{118}$ between the measure and the jurisdiction of the Member State granting it for the purposes of "preserv[ing] a factual or legal situation so as to safeguard [the claimant's] rights." ${ }^{119}$ Third, the measure may facilitate investigation concerned with the location, state or provenance of the cultural object, the effect of physical transfer of the object, or to ascertain how the party came to be in possession of the object. The definition of what constitutes a provisional or protective measure has not been specifically articulated by the Official Reports or the CJEU. A question remains as to whether jurisdiction over the substance $^{120}$ of the claim must have been first established, or is merely capable of being established. ${ }^{121}$ Whilst the Court of Justice in De Cavel $v$ De Cavel122 confirmed that measures under Article 31 are subject to equivalent rules on recognition and enforcement under the Brussels I Regulation, ${ }^{123}$ the Court in Denilauler v SNC Couchet Frères ${ }^{124}$ also confirmed that the enforcement of such measures in another Member State depends on whether the measure constitutes a judgment and how the enforcing court will give effect to it. ${ }^{125}$

The second option offered by the delegation proposed a narrower jurisdiction rule applicable "where the property belongs to the cultural heritage of a Member State... [or]

\footnotetext{
${ }^{116}$ CPR Rule 25.1 (1) (d).

${ }^{117}$ CPR 25.1 (1)(f).

${ }^{118}$ C-391/95 [1998] ECR I-7091 at 40; Hess, Pfeiffer, Schlosser, supra n 97, 290-291, paras 653-654, referring to Van Uden.

${ }^{119}$ Van Uden, ibid, para.37; Briggs and Rees, supra n 91, 644, para.6.10. Words in brackets added for emphasis.

${ }^{120}$ Briggs and Rees affirm that jurisdiction "to the claim for relief must still be established"; Briggs and Rees, supra $\mathrm{n}$ 91, 647, para. 6.11, emphasis added.

${ }^{121}$ Maher and Rodger, supra $\mathrm{n} 109,303,304-307$.

${ }^{122}$ C143/78 De Cavel v De Cavel [1979] ECR 1055.

${ }^{123}$ Newton, supra n 109, 295.

124 (125/79) Denilauler v SNC Couchet Frère [1980] ECR 1553.

125 Briggs and Rees, supra $\mathrm{n} 91,658-661$, para. 6.21.
} 
where the property is registered, in the courts of the Member State where the register is situated ..."126 The first part of this option was taken up by the European Parliament, which sought to justify the proposal as being "consistent" with other policy objectives for the protection of cultural objects. ${ }^{127}$ The final version of Article $7(4)$ of the Recast provides that:

“(A) person domiciled in a Member State may be sued in the courts of another Member State

4) as regards a civil claim for the recovery, based on ownership, of a cultural object as defined in point 1 of Article 1 of Directive 93/7/EEC initiated by the person claiming the right to recover such an object, in the courts for the place where the cultural object is situated at the time when the court is seised;" 128

\section{Article 7(4): scope and "counterbalance"129 to other grounds of jurisdiction in the Brussels I Recast}

As stated earlier, identification of the cultural object and the defendant ${ }^{130}$ with possession of it may be difficult to establish. There may be no prior relationship or connection between the claimant and defendant (who may be a thief, innocent bailee, custodier, third party holder or buyer). As considered earlier, a claimant must make a choice as to which special grounds of jurisdiction under Article 7 to use as an alternative to Article 4. A claim under Article $7(4)$ is brought in personam ${ }^{131}$ by the party claiming the right to recover in the place where the object is seized against a defendant domiciled in another Member State. The court seised will determine whether the property is classified as movable or immovable and the cause of action. The classification of movable property as a cultural object (defined by Directive

${ }^{126}$ Council of the European Union, CODEC 707, supra n 70, 2, word italicised for emphasis.

${ }^{127}$ European Parliament, "Amendment 121 Report," 25 September 2012 $<$ http://www.europarl.europa.eu/sides/getDoc.do?pubRef=-//EP//NONSGML+COMPARL+PE496.504+01+DOC+PDF+V0//EN\&language $=E N>$.

128 Words italicised for emphasis.

129 Hess, in Pocar (eds), supra n 2, 107.

130 In practice, either the possessor (Article 1(6)) or holder (Article 1(7)) of the cultural object; Directive 93/7/EEC.

${ }^{131} c f$ Reghizzi supra $\mathrm{n} 78,178$; words modified and removed for syntax. 
$93 / 7 / E E C)^{132}$ must be autonomous, ${ }^{133}$ particular to the objectives of the basis of jurisdiction and respectful of Member States' exclusive competence. As Recital 17 of Regulation EU 1215/2012 indicates, a claim for recovery under Article 7(4) "should be"134 based on ownership of a cultural object. In England the classification of a claim is akin to an "action for recovery"135 of movable property rather than a claim in tort for wrongful interference with proprietary rights (conversion). ${ }^{136}$

Reghizzi had reservations regarding the effectiveness of the original proposal for in rem jurisdiction over movable assets vis-à-vis concurrent claims. The incidence of concurrent claims may be limited to situations where a prior contractual relationship existed between the claimant (eg, a private individual or establishment such as a museum situated in a Member State) and the defendant who has or had possession of the object. However, Article 7(4) may enable a degree of flexibility as to who may be sued. Different defendants may be subject to Article 7(4). It will be necessary to consider whether or not the parties to the dispute have a prior existing relationship or contract which was breached by the defendant's conduct (wrongful removal to a third jurisdiction or retention beyond an agreed contractual period in line with Directive EU 93/7). ${ }^{137}$ This will be fact-dependant, requiring the claimant to make a decision as to the principal basis on which to make a claim. As Recital 17 suggests, it will also be necessary to consider how the object came to be present in a particular

\footnotetext{
${ }^{132}$ Cf footnote to revised Directive; Forrest, supra n 4, 148.

${ }^{133} \mathrm{G}$ Maher and B J Rodger, supra $\mathrm{n} 79,108$.

${ }^{134}$ Recital 17, Regulation EU 1215/2012.

135 Dicey and Morris, supra n 71, para. 34-020 ; Council of the European Union, "Comments from the delegation of Cyprus relating to Article 5(2)," JUSTCIV 223, supra $\mathrm{n} 88,2$.

136 Dicey and Morris, supra n 71, para 34-022. Depending on the prior connections between the parties, the claim may also be characterised as a breach of contract.

${ }^{137}$ An important distinction between removal and retention for choice of law purposes is made by Carruthers; the former being an example of "involuntary dispossession," the latter "voluntary"; Carruthers supra n 39, 265 at footnote 85 .
} 
jurisdiction (due to an initial or subsequent wrongful removal or (subsequent) transfer to the jurisdiction, in breach of lawful possession). A cultural object may be either wrongfully removed, retained (ie "not returned"138) or both. More than one defendant may be involved in these acts. To satisfy a claim for breach of contract under Article 7(1)(a), the defendant would have to remain in possession beyond the contractual term agreed or have transferred possession of the object to a third party in breach of contract. ${ }^{139}$ There may be an analogous claim in tort against the defendant in such a situation, but such a claim must be brought under Article 7(2).

(a) "a civil claim for the recovery, based on ownership, ..."

The effective interpretation of this phrase will be crucial to the utility of Article $7(4)$. The objective of this special jurisdiction rule is, per Recitals 15 and 16 of the Recast, premised on a "predictable"140 jurisdiction rule which offers a "close connection"141 (the location of the object) with the forum. The phrase "civil claim for recovery" within Article 7(4) underpins the rationale for such proceedings, distinct from the alternative, special jurisdictional bases in contract and tort. To be of any value to a litigant, the phrase "based on ownership" requires to be carefully interpreted, irrespective of the Member State in which proceedings are brought. There are two ways in which the Court of Justice may approach the interpretation of the phrase "based on ownership." One way may be to allude to the approach of Article 12 of Directive EU 93/7 and Article 36 TFEU $^{142}$ by analogy. Both Article 12 of Directive EU 93/7

\footnotetext{
${ }^{138}$ European Commission, "Proposal For a Directive of The European Parliament and of The Council on The Return of Cultural Objects Unlawfully Removed From The Territory of a Member State (Recast)," 2013/0162 (COD), 16 specifically proposed Articles 2(a) and (b).

${ }^{139}$ Carruthers, supra n 39, 265.

140 Recital 15, EU 1215/2012.

141 Recital 16, EU 1215/2012.

${ }^{142}$ Classification may operate prospectively; Article 14, Directive 93/7/EEC; 2013/0162 (COD), proposed Article 1.
} 
and Article 12 of Directive EU 2014/60, when it comes into force later this year, confirm that "(O)wnership of the cultural object after return shall be governed by that law of the requesting Member State." ${ }^{143}$ If Article 7(4) is to be read and interpreted in line with Directives EU 93/7 and 2014/60, the putative applicable law may be the law of the Member State where the claimant has a valid and persisting right of ownership over the object. However, this presupposes that this is the originating Member State (lex originis) ${ }^{144}$ which classified the object as a national treasure prior to its unlawful removal or retention and the party wishes to rely upon that law for the basis of its claim for recovery. Alternatively, the phrase "based on ownership" may be interpreted through the enforcement of an earlier judgment asserting ownership ${ }^{145}$ from the courts of another Member State. Even though Regulation EC 1215/2012 facilitates automatic recognition and limits grounds for refusal to enforce judgments, the effective enforcement of the judgment is still dependent upon establishing the object's location. As a result, this approach is tenuous and the first approach is preferred in support of an autonomous interpretation.

(b) "initiated by the person claiming the right to recover such an object ..."

Article $7(4)$ requires a civil claim for recovery to be based both on a party continuing to retain ownership of a cultural object, thereby entitling that party with a right to recover that object. As stated above, the claimant will have to demonstrate prior ownership, probably under the law of the originating Member State. As the previous paragraph considered, Article 7(4) raises the importance of interpreting the meaning of "the right to recover..." based on ownership. ${ }^{146}$

\footnotetext{
${ }^{143}$ Article 12 Directive 93/7/EEC; proposed Article 12, 2010/0383(COD), supra n 98, 21; Directive EU 2014/60, supra $\mathrm{n} 21$.

${ }^{144}$ Carruthers, supra $\mathrm{n} 39,265-269$.

${ }^{145}$ Forrest, supra n 4, 152 (citing the US case United States v An Antique Platter of Gold 991 F.Supp 222 (SDNY, 1997), aff'd 184 F.3d 131 ( $2^{\text {nd }}$ Cir. 1999)).

146 P Rogerson, Collier's Conflict of Laws, (4 ${ }^{\text {th }}$ ed, Cambridge University Press, 2013), 51.
} 
Whilst the delegation of Cyprus confirmed that Article 7(4) "does not (and could not) address the question of which substantive law will be applied by the courts of the situs Member State, ${ }^{\prime 147}$ the use of Article $7(4)$ in practice will provide an opportunity to affirm the role of the court seised in classifying and applying foreign law ${ }^{148}$ at the jurisdiction stage and the role of the Court of Justice in interpreting this aspect of Article 7(4). Two observations may be offered. The first observation is that when a claim requires reference to a foreign law, the party seeking to rely on that foreign law must generally plead and prove the foreign law in accordance with the law of the court seised. The procedural basis for asserting and proving a foreign law remains distinct in each Member State, with approaches to foreign law varying from a "peculiar"149 fact, a "special"150 fact or "law of a different kind." ${ }^{151}$ For example, Rule 137 of Dicey and Morris confirms that the English courts will enforce a property right "if the act was valid and effective by the [lex situs]." ${ }^{152}$ Decisions of the English courts such as National Bank of Greece and Athens SA v Metliss ${ }^{153}$ and Bumper Development Corp., Ltd v Metropolitan Commissioner of Police ${ }^{154}$ both affirm the need to foster comity of nations through claims for the return of cultural objects. Whilst Hartley ${ }^{155}$ regarded the distinction vis-à-vis foreign law as innocuous in practice, if the "sui generis" special jurisdiction rule is to secure greater coordination of proceedings for the effective return of cultural objects, the

\footnotetext{
${ }^{147}$ Council of the European Union, "Comments from the delegation of Cyprus relating to Article 5(2)," JUSTCIV 223, supra n 88, 3.

${ }^{148}$ C Esplueges, J L Iglesias and G Palao (eds), Application of Foreign Law (Sellier: European Law Publishers, Munich, 2011), 91.

149 T C Hartley, "Pleading and Proof of Foreign Law: The Major EU Systems Compared," (1996) 45 International and Comparative Law Quarterly 271, 272.

${ }^{150}$ Rogerson, supra $\mathrm{n} 74,247$.

151 Parkasho v Singh [1968] P. 233, 280 per Cairns J.; Hartley, supra n 149, 272.

152 Dicey and Morris, supra n 71, Rule 137, Chapter 25.

153 National Bank of Greece and Athens SA v Metliss [1958] AC 509.

${ }^{154}$ Bumper Development Corp., Ltd v Metropolitan Commissioner of Police [1991] 1 WLR 1362, CA.

155 Hartley, supra n 149.
} 
distinction must be reflected in an autonomous interpretation of the phrase "a claim ... based on ownership ..."

The second and wider observation is whether an approximated public policy rule for the enforcement of foreign law is also necessary for the protection of cultural objects? As far as the English courts are concerned, the general premise is that foreign "illegal, penal or public" 156 laws are not applied by the court. However, as Rogerson reminds us, the distinction is not clear cut since their classification "turn[s] on the drafting of the original law and its unpredictable interpretation by the English courts." 157 Once classified, the "critical" 158 issue is whether or not the applicable law (lex situs or the foreign law relied upon by the claimant) requires the claimant to have legal possession of the cultural object. As far as the English courts are concerned, if possession is established according to foreign law (not one of the three categories referred to above), that law will be recognised by the English courts. ${ }^{159}$ In Government of Iran v Barakat $L t d^{160}$ various cultural objects had been unlawfully excavated from Iran and passed through Europe in order that good title could be acquired for the purposes of sale. The Government of Iran brought proceedings in the English courts for recovery of the objects on the basis that the objects were part of Iranian national heritage. The question at first instance was whether the Government of Iran could make a claim in conversion under English law for the return of the objects or were barred from doing so by seeking enforcement of a foreign public law. On appeal, the English Court of Appeal classified the claim, and the relevant Iranian law, as patrimonial ${ }^{161}$ enabling the Iranian Government to

\footnotetext{
${ }^{156}$ Rogerson, supra n 74, 247.

${ }^{157}$ Rogerson, supra $\mathrm{n} 74,249$. Word modified for syntax.

${ }^{158}$ Rogerson, supra $\mathrm{n} 74,249$.

${ }^{159}$ Forrest, supra n 4, 153.

160 [2007] ECWA Clv 1374.

161 Dicey and Morris, supra n 71, para 24-012; Chong, supra n 3, 107 and Rogerson, supra n 74, 248.
} 
proceed with the claim. Whilst the wider effect of the Barakat case may be to generate greater "reciprocity"162 between the English courts and foreign States seeking the return of their cultural objects, subsequent views of the English Court of Appeal's approach in this case have been divisive. Some favour this approach from the perspective of comity, whilst others maintain that the approach taken by the English Court of Appeal has not improved legal certainty at all. ${ }^{163}$ These criticisms highlight the point made by Hartley ${ }^{164}$ and more recently by Esplueges et a ${ }^{165}$ who conclude, inter alia, that irrespective of different traditions and categorisations of foreign law, differing systems of civil justice across the Member States continue to have the greatest impact upon the success of a claim based on a foreign law.

The reliance on foreign law as the basis of a "claim for recovery, based on ownership" will continue to present both a challenge and an opportunity in securing the recovery of cultural objects. As Chong observes, the opportunity may be "used to give effect to a fundamental human right"166 whereas the challenge "may lead to the application of an otherwise inapplicable foreign public law protecting that state's cultural heritage." ${ }^{167}$ These competing interests will have to be reconciled in determining how "recovery, based on ownership" is interpreted by the CJEU. In the meantime, the enforcement of foreign law will continue to be restricted only where it is manifestly incompatible with the public policy of the court seised.

\footnotetext{
162 Chong, supra n 3, 107.

163 Rogerson, supra $\mathrm{n} 74,249$ and supra $\mathrm{n}$ 146, 405.

164 Hartley, supra n 149, 291-292.

165 Esplueges et al, supra n 148, 6, 7-8, 70, 90.

${ }^{166}$ Chong, supra $\mathrm{n} 3,113$.

${ }^{167}$ Chong, ibid.
} 
(c) "...in the courts for the place where the object is situated ..."

Article 7(4) jurisdiction is established "in the courts for the place where the object is situated at the date the court is seised." The first part (ergo the sufficiently "close link"168) is the "courts for the place where the cultural object is situated." Applying the Court of Justice's decision in Color Drack GmbH v Lexx International Vertriebs $\mathrm{GmbH}^{169}$ by way of analogy, Article $7(4)$ should enable a claimant to raise proceedings in one or more courts of the place within a Member State where the object is situated. This may provide the claimant with flexibility in situations where the object has been moved within or to another Member State or, where provisional measures are not available, were not granted or cannot extend on an extraterritorial basis ${ }^{170}$ to another Member State.

(d) "... at the time when the court is seised."

Since tangible, movable property may be more readily displaced than other forms of property, Article $7(4)$ seeks to establish the point in time when the cultural object is deemed to be situated in a Member State. Article 32 of the Recast ${ }^{171}$ confirms the position under the current Regulation. The date on which the court is seised depends upon whether the documents were lodged with the court (Article $31(1)(a)$ ) or were served in advance (Article 32(1)(b)). In practice, the success of a claim under Article 7(4) may depend on whether the defendant has knowledge of an impending claim under Article 7(4) and attempts to "displace"172 the cultural

\footnotetext{
168 Reghizzi, supra n 78, 174.

${ }^{169}$ Color Drack GmbH v Lexx International Vertriebs GmbH [2007] ECR I-3699; Wood Floor Solutions Andreas Domberger GmbH v Silva Trade SA [2010] ECR I-2121.

${ }^{170}$ Briggs and Rees rightly highlight that irrespective of the defendant's domicile, there is an underlying need for consistency when applying relief on an extra-territorial basis; Briggs and Rees, supra $\mathrm{n}$ 91, 651, para. 6.14. ${ }^{171}$ P Neilsen, "The New Brussels I Regulation," (2013) 50 Common Market Law Review 503, 517-518, who also suggests that Article 32 will apply in determining when the court of a non-Member State is seised for the purposes of Section 9 (lis pendens).

172 Reghizzi, supra $\mathrm{n} 78,176$; word modified for syntax.
} 
object to another jurisdiction, prior to the court becoming seised. The time the court is seised is pivotal to Article 7(4) being established, regardless of subsequent events. As stated earlier, the opportunity for provisional or protective measures under Article 35 should be assessed at the earliest stage of proceedings.

\section{Conclusion: the utility of the conflict of laws in facilitating demand side regulation of}

\section{cultural objects}

This article has sought to consider the jurisdictional basis for private claims for the recovery of cultural objects in the courts of a Member State introduced by Article 7(4) of Regulation EU $1215 / 2012$. This special jurisdiction rule is a welcome development towards facilitating the return of a cultural object - from a place of market demand or where the object is in transit- to a party asserting ownership. However, in practice the utility of this special jurisdiction rule will depend upon its scope and interpretation by the Court of Justice together with its ability to offer a "counterbalance"173 to Article 4 and the other special grounds of jurisdiction in the Regulation. In a similar fashion to when a claimant decides whether to sue either under Article 7(1) or 7(2), Article 7(4) will also be treated as a distinct special jurisdiction rule under the Brussels I Recast which will operate as an alternative to Article 4. Crucial to the effectiveness of Article 7(4) for the coordination of claims against EU domiciliaries will be an autonomous interpretation of a number of key elements. One such key phrase is "a claim, based on ownership." If an autonomous interpretation is sought, this phrase must be interpreted with due regard to Article 12 of Directlve EU 2014/60, when it comes into force. The scope of Article 7(4) applies to claims "initiated by the person claiming the right to recover such an object." This too, will require to be autonomously interpreted so that the special

\footnotetext{
${ }^{173}$ Hess, in Pocar, Viarengo and Villata (eds), supra n 2. Word modified for syntax.
} 
jurisdiction rule assures "intended results through the avoidance of fortuitous connecting factors." ${ }^{174}$ Another key phrase in Article 7(4) is the link between the claim and "courts for the place where the object is situated at the time when the court is seised." This phrase should also be interpreted to enable proceedings to be brought in that part of a Member State where the object is situated, at a time which accords with Article 31(1)(a) of the Brussels I Recast. Finally, in an attempt to prevent further displacement of the cultural object between jurisdictions, Article 35 should be utilised through the application of Member States' provisional or protective measures. This paper concludes that the special jurisdiction rule is a key step towards the EU leading a "transnational policy of protection of cultural property."175 Whilst further approximation of both applicable law and rules to determine the application (proof) of foreign law in claims for the recovery of cultural objects are distant objectives, the value of the sui generis jurisdiction rule at EU level will be to contribute towards the return of cultural objects removed from or present in Member States where demand shifts as markets change, which in turn will increase intra-EU and external cooperation for the recovery of cultural objects.

${ }^{174}$ Case C-218/12 Lokman Emrek v Vlado Sabranovic, ECLI:EU:C:2013:666 at para 17.

175 Chong, supra $\mathrm{n} 3$. 